\title{
Inheritance of Phytophthora Root Rot and Foliar Blight Resistance in Pepper
}

\author{
Stephanie J. Walker ${ }^{1}$ and Paul W. Bosland ${ }^{2}$ \\ Department of Agronomy and Horticulture, New Mexico State University, Las Cruces, NM 88003
}

AdDitional INDEX wORDs. Phytophthora capsici, chile wilt, disease resistance, vegetable breeding

\begin{abstract}
The inheritance of resistance to Phytophthora capsici Leonian root rot and foliar blight was compared in two different Capsicum annuum L. var. annuum pod types. The seedling was screened for phytophthora root rot, while a genetically identical stem cutting was screened for phytophthora foliar blight to determine if the same gene(s) confer resistance to both disease syndromes. The susceptible parents were 'Keystone Resistant Giant \#3' ('Keystone'), a bell pepper type, and 'Early Jalapeño', while 'Criollo de Morelos-334' was the resistant parent. Resistance was observed in both $F_{1}$ populations screened for phytophthora root and foliar infection indicating dominance for resistance. Reciprocal effects were not detected. To determine if the same gene(s) conferred root rot and foliar resistance, root rot screening results were matched to the corresponding foliar blight stem cutting reaction. The segregation of resistance in the $F_{2}$ generations was dependent on the susceptible parent. In the $F_{2}$ generation derived from 'Early Jalapeño', root rot resistance and foliar blight resistance segregated in a 9:3:3:1 (root resistant/foliar resistant : root resistant/foliar susceptible : root susceptible/foliar resistant : root susceptible/foliar susceptible) ratio. One independent, dominant gene was necessary for root rot resistance, and a different independent, dominant gene was needed for foliar blight resistance. In the $F_{2}$ generation derived from 'Keystone', root rot and foliar blight resistance segregated in a 7:2:2:5 (root resistant/ foliar resistant : root resistant/foliar susceptible : root susceptible/foliar resistant : root susceptible/foliar susceptible) ratio. This segregation ratio is expected when one dominant gene is required for root resistance, and a different dominant gene is required for foliar resistance. In addition to these two genes, at least one dominant allele of a third gene must be present for expression of root rot and foliar blight resistance.
\end{abstract}

One of the most economically destructive pathogens to chile (Capsicumannuum L.) worldwide is Phytophthora capsici Leonian (Barksdale et al., 1984; Goldberg, 1995). Phytophthora capsici is a soilborne pathogen that was first identified as the causative agent of chile wilt in a field near Las Cruces, New Mexico in 1918 (Leonian, 1922). Since that time, phytophthora root rot has continued to be a persistent problem in New Mexico as well as in chile production areas throughout the world (Goldberg, 1995).

Depending on the point of infection, $P$. capsici may cause several different disease syndromes in chile. These include root rot, foliar blight, and pod rot (Alcantara and Bosland, 1994; Goldberg, 1995). Conditions conducive to phytophthora root rot are saturated soil for extended periods and warm soil temperatures. This may occur following heavy rainfall or excessive irrigation. In fact, field moisture from rainfall and irrigation has more of an effect on the final severity of disease in a field than the initial concentration of inoculum (Ristaino, 1991). Low or shaded spots in a field may be susceptible to Phytophthora outbreaks due to slow drying in these areas (Bosland and Lindsey, 1991; Goldberg, 1995).

Although root rot is the most destructive form of the disease in irrigated agriculture, phytophthora foliar blight may also result in serious losses when soil containing $P$. capsici contacts leaves by way of splashed rain or during cultivation and harvest of wet fields. Foliar blight symptoms include dark, water soaked areas on the leaves. Infected leaves turn straw colored and may defoliate from the plant as the infection spreads to the stem. Unlike phytophthora root rot, where infected chile plants die from the roots up due to wilt, foliar infection spreads from the leaves to the stems, thereby killing an infected chile plant from the leaves downward (Alcantara and

Received for publication 20 Apr. 1998. Accepted for publication 18 Oct. 1998. A contribution of the New Mexico Agricultural Experiment Station, New Mexico State Univ., Las Cruces, NM 88003. The cost of publishing this paper was defrayed in part by the payment of page charges. Under postal regulations, this paper therefore must be hereby marked advertisement solely to indicate this fact.

${ }^{1}$ Research assistant.

${ }^{2}$ Professor.
Bosland, 1994; Goldberg, 1995; Lindsey et al., 1996; Weber, 1932). Several different screening methods have been developed to distinguish Phytophthora resistant individuals from susceptible individuals (Alcantara and Bosland, 1994; Barksdale et al., 1984; Bosland and Lindsey, 1991; Bowers and Mitchell, 1991; Gil Ortega et al., 1991). Researchers have identified Capsicum anпиит accessions that possess resistance to Phytophthora capsici. Germplasm exhibiting resistance to phytophthora root rot includes 'Line 29', 'USDA PI201232', 'USDA PI201234', as well as 19 land races found in the Mexican state of Morelos, grouped together as 'Criollo de Morelos' (Alcantara and Bosland, 1994; Bartual et al., 1994; Bosland and Lindsey, 1991; Gil Ortega etal., 1991; Guerrero-Moreno and Laborde, 1980). Of these varieties, 'Criollo de Morelos-334' ('CM-334') has consistently exhibited the highest degree of resistance to $P$. capsici. Resistance by 'CM-334' was demonstrated when the plants were screened for phytophthora root rot and foliar blight using a locally obtained P. capsici isolate, PWB-24 (Bosland and Lindsey, 1991; Alcantara and Bosland, 1994).

Previous studies on the genetics of resistance of 'CM-334' to Phytophthora capsici have generated conflicting results (Gil Ortega et al., 1991; Guerrero-Moreno and Laborde, 1980; Reifschneider et al., 1992). Disparities may have been caused by inconsistency in experimental designs, or by different genetic backgrounds of the susceptible parents. An additional contributing factor may have been the use of screening methods that did not account for the possible existence of different modes of inheritance for different infection sites on the plant. Researchers have previously suggested that different genetic mechanisms may be responsible for resistance to phytophthora root rot and phytophthora foliar blight (Barksdale et al., 1984). A similar situation exists in the hostpathogen relationship of another Phytophthora species [Phytophthora infestans (Mont.) de Bary] and potatoes (Solanum tuberosum L.), a close relative of chile (Budin et al., 1978). Late blight in potato, caused by $P$. infestans, was one of the early targets for studies into genetics of resistance. Early in their efforts, potato breeders discovered that a potato variety possessing tuber resis- 
tance did not necessarily possess vine or foliage resistance in the same plants to the same race of $P$. infestans (Bonde et al., 1940; Rudorf et al., 1950). Conversely, some potato varieties would exhibit vine resistance, but tuber susceptibility. In fact, many potato varieties bred for foliage resistance had very susceptible tubers, presumably because tuber resistance genes were not brought along during the breeding process (Howard, 1978). The implication of such differences in susceptibility to an identical race of $P$. infestans is that different genes are responsible for resistance in different tissues of the potato plant.

To identify a similar division of genetic resistance in different tissues of chile plants, very precise and specific screening methods for the different disease syndromes must be used. Previous efforts in the identification of chile cultivars resistant to $P$. capsici have frequently entailed inoculating entire plants from the leaf crown down to the roots, thereby not differentiating between root and foliar resistance. Before the recent development of root rot and foliar blight screening techniques (Alcantara and Bosland, 1994; Bosland and Lindsey, 1991), it could not be conclusively proven whether gene interactions that provide resistance to phytophthora root rot and phytophthora foliar blight are under separate genetic control. The discovery of separate resistance mechanisms would have important implications towards breeding chile cultivars resistant to $P$. capsici. Genes for resistance to both disease syndromes would have to be introgressed into a commercial cultivar to obtain resistance to both types of Phytophthora infection.

To determine if resistance to phytophthora root rot and foliar blight are conferred by the same gene(s), the exact same plants should ideally be screened for both disease syndromes. Unfortunately, if screened plants are susceptible to one form of Phytophthora infection, the same plant cannot be unbiasedly screened for the other disease syndrome. If a plant has not already died, it may be in a weakened state and therefore more susceptible to infection than if in a healthy condition. Because screening the exact same plant for root rot and foliar blight is not practical, the best option is to screen genetically identical clones. Stem cuttings allow for genetically identical clones to be produced, and thereby enables testing separately for root rot and foliar blight.

\section{Materials and Methods}

Plant preparation. Two commercially available chile cultivars, 'Early Jalapeño' and 'Keystone Resistant Giant \#3' were the susceptible parental lines. The susceptible parents were selected due to their complete vulnerability to root and foliar infection by Phytophthora capsici. 'Criollo de Morelos-334', which has consistently shown a high degree of resistance to root rot and foliar blight, was the resistant parent. The seed for the three parental accessions was obtained from lines maintained by the New Mexico State University chile breeding program.

Seeds were sown in $3.9 \times 2.7 \times 5.5 \mathrm{~cm}$ compartments of 12 celled bedding plant containers (Hummert International, Earth City, MO, cat\# 11-0450) containing a commercially prepared peat moss-vermiculite soil mixture (Peatlite, Scotts-Sierra Horticultural Products Co., Marysville, Ohio). The bedding plant containers were placed in planting trays (Hummert International, Earth City, MO, cat\# 11-3000). To promote seed germination, the trays were placed on propagation pads that maintained a soil temperature of 28 to $32{ }^{\circ} \mathrm{C}$. The trays were watered daily as needed. Following germination, $\approx 1.8 \mathrm{~g}$ of slow-release fertilizer beads (Osmocote, 14-6.2-11.6, Scotts-Sierra Horticultural Products Co.) were placed on the soil surface of each bedding plant container.

Initially, at least 22 plants from each of the three parental acces- sions were screened for their reaction to foliar blight and root rot. Susceptible parents, 'Keystone Resistant Giant \#3' and 'Early Jalapeño', were reciprocally crossed with the resistant 'Criollo de Morelos-334' to obtain $\mathrm{F}_{1}$ progeny. Self-pollinated fruits were harvested from $F_{1}$ plants to obtain the $F_{2}$ generation. $F_{1}$ plants were also backcrossed to their respective susceptible parent to obtain testcross plants.

STEm CuTtings. Stem cuttings were made of the parental lines, $\mathrm{F}_{1}$, $\mathrm{F}_{2}$, and testcross plants so that two genetically identical plants were available for screening. In each case, the original plant was screened for root rot, and the cutting generated clone was screened for foliar blight. Stem cuttings were made from 6- to 8-week-old plants through a standard method of cutting propagation (Hartmann et al., 1990). Using a sharp razor, sanitized with an ethanol spray, the top of each plant was cut off just below a node, with at least one true leaf remaining on the plant above and below the point of detachment. The stem of the cutting was lightly scored and dipped in a rooting compound (RooTone, The Security Products Co. of Delaware Inc., Minneapolis, Minn.). Cuttings were then quickly inserted into a plant cell containing moist peat moss-vermiculite soil mixture. Both the original plant and the cutting derived from the plant were tagged with the same unique plant identification number. The cuttings were placed on a propagating bed composed of propagation pads, a mist system, and entirely covered by shade cloth. The propagation pads maintained the soil temperature at 28 to $32^{\circ} \mathrm{C}$. A water mist was sprayed over the cuttings every 12 min during daylight hours to keep the cuttings turgid. The shade cloth filtered $\approx 50 \%$ of the incoming sunlight to prevent excessive transpiration by the cuttings. After 2 to 3 weeks a root system had sufficiently developed on the cuttings. They were then removed from the mist table and transplanted into single cell $8.0 \times 8.0 \times 5.5 \mathrm{~cm}$ plastic plant containers (Hummert International, Earth City, Missouri, cat\# 11-0750). The peat mossvermiculite soil mixture was used as the transplanting medium. Stem cuttings that died or lost vigor due to the cutting process were discarded. About $3 \mathrm{~g}$ of slow release fertilizer beads (Osmocote, 14 6.2-11.6) were placed on the top of the soil of each transplant. The plants were removed from the propagation bed and allowed to harden in the greenhouse for at least 2 weeks before being subjected to foliar blight screening.

INOCULUM PREPARATION. A highly virulent Phytophthora capsici isolate (PWB-24) that was isolated from an infected chile plant in a local New Mexico field was used in all the screening tests. The $P$. capsici was maintained on water agar during long-term storage (Tuite, 1969). To make inoculum, agar plugs $1 \mathrm{~cm}$ in diameter were aseptically taken from $P$. capsici cultures, and one plug was centrally placed on each $100 \times 20$-mm polystyrene petri dish containing sterile V-8 juice agar medium (Tuite, 1969). The pure cultures of $P$. capsici were grown on the $\mathrm{V}-8$ agar for $7 \mathrm{~d}$ in an incubator at $25^{\circ} \mathrm{C}$. After $7 \mathrm{~d}$, agar plugs $1 \mathrm{~cm}$ in diameter were aseptically removed from the 1 -week-old cultures and transferred to $150 \times 15-\mathrm{mm}$ sterile polystyrene petri dishes. Twenty $P$. capsici agar plugs were evenly spaced in each petri dish. The petri dishes were flooded with sterile glass-distilled water to the top of the agar plugs. The sterile water was maintained at the same temperature as the cultures. The flooded plates were then returned to the incubator. After 2 to $3 \mathrm{~d}$, the water was aseptically siphoned off with a sterile pasteur pipet and replaced with new sterile, distilled water. The newly flooded plates were again placed in the incubator for 2 to $3 \mathrm{~d}$. After that time, the plates were placed in a refrigerator at 10 ${ }^{\circ} \mathrm{C}$ for $1 \mathrm{~h}$ to induce release of zoospores. The plates were then removed from the refrigerator and left at room temperature $(\approx 27$ ${ }^{\circ} \mathrm{C}$ ) for $30 \mathrm{~min}$. The liquid containing the zoospores was then siphoned from the plates. The number of zoospores $/ \mathrm{mL}$ was 
determined by direct count under $10 \times$ magnification utilizing a hemacytometer. The inoculum was diluted to obtain 40,000 zoospores $/ \mathrm{mL}$ if the intended use was for foliar blight screening. A dilution of 2,000 zoospores/mL was made if the inoculum was intended for root rot screening. These zoospore concentrations have been determined to differentiate genetically resistant plants from susceptible plants (Alcantara and Bosland, 1994; Bosland and Lindsey, 1991; Reifschneider et al., 1986).

ROOT ROT INOCULATION. Seven bedding plant containers (Hummert International, Earth City, Mo., cat\# 11-0450) containing up to 12 plants each, were positioned in each planting tray (Hummert International, cat\# 11-3000) in a randomized complete block design with four replications. The trays of plants were placed in nohole planting trays (Hummert International, cat\# 11-3050) and watered so that the soil was saturated. When screening for root rot, $5 \mathrm{~mL}$ of inoculum (a total of 10,000 zoospores) was introduced into the soil of each cell. Immediately following inoculation, the planting trays were flooded with water. The roots were kept in a flooded condition for 2 to $3 \mathrm{~d}$ after inoculation to ensure root contact by the zoospores. The seedlings were then removed and drained. The plants were watered as needed, once or twice per day, to promote optimum plant growth. Plants were scored when the susceptible control plants developed severe disease symptoms, averaging a score of $\geq 7$.

Plants were scored based on the following disease interaction phenotype scale: $1=$ no disease symptoms; $3=50 \%$ or less darkening of visible roots, slight stunting; $5=$ greater than $50 \%$ darkening of visible roots, small stem lesion, stunted plant; $7=$ brown roots, large girdling stem lesion, plants wilted and stunted; $9=$ death. Even numbered scores were used when symptoms were between categories. For example, a score of 2 was assigned to plants that exhibited slight root darkening but with overall robust health. Plants that received a score of 1 or 2 were classified as resistant to phytophthora root rot. Plants that received a score of 3 or greater were classified as susceptible to phytophthora root rot.

Foliar BLight INOCUlation. Before inoculation, three healthy and undamaged leaves per plant were selected for inoculation. Proper selection of leaves for inoculation was an important step in securing a reliable test. Leaves selected were positioned horizontally, so that the inoculum droplet would not slide off the leaf during the infection period. Leaves that were excessively tilted caused the inoculum to either run off the plant before infection could occur, or run towards the plant and contaminate the stem portion of the plant. Each leaf selected was marked with the specific plant identification number using a permanent ink, fine-tipped marking pen. Foliar blight screenings were performed in a dew chamber. The dew chamber was constructed of polyethylene plastic, and sealed to prevent excessive loss of moisture (Alcantara and Bosland, 1994). The relative humidity was maintained between $80 \%$ to $100 \%$ with the continuous use of an ultrasonic humidifier placed within the chamber. Plants were placed in the dew chamber just before inoculum application. A completely randomized design with seven replications was employed. Using a micropipet, a 40 - to $50-\mu \mathrm{L}$ droplet of inoculum $(\approx 1,800$ zoospores/leaf) was carefully placed on each marked leaf. After $5 \mathrm{~d}$, plants were removed and scored based on expression of disease symptoms.

Plants were scored by the following disease interaction phenotype scale: $1=$ no disease symptoms; $3=5$ to $10 \%$ of inoculated leaf area with active, water-soaked lesions; $5=>10$ to $40 \%$ of inoculated leaf area with active, water-soaked or scalded areas; $7=>40$ to $70 \%$ of inoculated leaf area with active, water-soaked or scalded areas; $9=$ $>70 \%$ of the total inoculated leaf area necrotic. Even numbered scores were used when symptoms fell between categories. For example, a score of 2 was assigned to plants that exhibited a static scald mark covering less than 5 percent of the total inoculated leaf area. Plants scored as a 1 or 2 were classified as resistant. A score of 3 or greater indicated that the plant was foliar blight susceptible.

To determine the probable number of genes, each segregating population was compared to hypothetical segregation patterns by the chi-square test for goodness of fit. Exact $P$ values were obtained using the SAS computer program (SAS Institute Inc., Cary, N.C.). For the combined root rot and foliar blight analysis, data were taken only from $\mathrm{F}_{2}$ and testcross plants that had been screened for root rot and foliar blight. If either the original plant or its clone died before disease screening, neither plant was included in the data analysis. Plants were placed in one of four categories. Plants that were root rot resistant and foliar blight resistant were designated as ' $R / R$ '. Plants were designated as ' $R / S$ ' if root rot resistant, but foliar blight susceptible. Plants were designated as 'S/R' if susceptible to root rot infection, but foliar blight resistant. If plants were root rot susceptible and foliar blight susceptible, they were designated as ' $\mathrm{S} / \mathrm{S}$ '.

\section{Results}

Phytophthora root rot. The 'Keystone' and 'Early Jalapeño' susceptible controls, randomly positioned in each test tray, all exhibited phytophthora root rot symptoms. Disease interaction phenotype scores ranged from 3 to 9 . Resistant control plants of 'CM-334' randomly placed in each tray did not display phytophthora root rot symptoms, and uniformly received a disease interaction phenotype score of 1 .

The $F_{1}$ plants obtained from the reciprocal crosses of 'Early Jalapeño' and 'CM-334' and the $\mathrm{F}_{1}$ plants obtained from the reciprocal crosses of 'Keystone' and 'CM-334' were all resistant to phytophthora root rot. This indicates that inheritance of resistance was dominant for both plant populations and resistance is not affected cytoplasmically.

To determine the number of genes necessary for root rot resistance, the segregation of the $\mathrm{F}_{2}$ and testcross populations was analyzed using the chi-square test for goodness of fit. In the $\mathrm{F}_{2}$ population derived from the 'Early Jalapeño' susceptible parent the segregation fit a 3:1 (resistant/susceptible) ratio (Table 1). This ratio is consistent with a single dominant gene inheritance pattern. The 'Early Jalapeño' testcross generation fit a 1:1 segregation ratio (Table 1), further substantiating that a single gene confers root resistance when 'Early Jalapeño' is the parent.

Segregation in the $\mathrm{F}_{2}$ populations derived from the 'Keystone' and 'CM-334' crosses fit a 9:7 ratio (Table 1) indicating that two dominant genes were segregating. The 'Keystone' testcross population fit a 1:3 segregation pattern (Table 1) which further corroborated that two genes must be acquired by offspring derived from the 'Keystone' cross for root rot resistance.

Phytophthora foliar blight. The 'Keystone Resistant Giant \#3' and 'Early Jalapeño' susceptible controls all exhibited phytophthora foliar blight symptoms. Disease interaction phenotype scores ranged from 3 to 9. 'Criollo de Morelos-334' resistant control plants, exhibited no foliar symptoms or displayed small, static scald marks. All resistant control plants received disease interaction phenotype scores of either 1 or 2 , denoting resistance to phytophthora foliar blight.

When subjected to phytophthora foliar blight screening, all $F_{1}$ plants obtained from the reciprocal crosses of 'Early Jalapeño' and 'CM-334', and 'Keystone' and 'CM-334' were resistant to phytophthora foliar blight. This indicates that the resistance was dominant, and that a cytoplasmic effect was not active. 
To determine the number of genes necessary for phytophthora foliar blight resistance, the segregation of the $F_{2}$ and testcross populations was analyzed. In the $\mathrm{F}_{2}$ population derived from 'Early Jalapeño' and 'CM-334' (Table 2), a 3:1 (resistant/susceptible) ratio was observed. This confirmed that a single dominant gene conferred resistance. The testcross population to 'Early Jalapeño' (Table 2) yielded a ratio of 1:1 (resistant/susceptible). The testcross population confirmed that a single dominant gene conferred resistance to foliar blight in this cross.

In the $\mathrm{F}_{2}$ population derived from 'Keystone' and 'CM-334' (Table 2), a 9:7 (resistant/susceptible) ratio was observed which indicated that two genes were needed for foliar blight resistance. The testcross to 'Keystone' (Table 2) segregated 1:3 (resistant/ susceptible) and confirmed that two genes were necessary for foliar resistance when 'Keystone' was used as a parent.

COMPARISON OF ROOT ROT RESISTANCE TO FOLIAR BLIGHT RESISTANCE. When the segregation ratio of the $\mathrm{F}_{2}$ population derived from 'Early Jalapeño' and 'CM-334' was determined for root rot and foliar blight, it yielded a 43:16:19:11 (R/R:R/S:S/R:S/S) ratio. This segregation fit a $9: 3: 3: 1$ ratio $\left(\chi^{2}=6.66 ; P=0.08\right)$, confirming that two independent genes, one for root resistance and one for foliar resistance, were needed for resistance. The 'Early Jalapeño' testcross data for root rot and foliar blight resulted in a 21:14:10:13 (R/R:R/S:S/R:S/S) ratio. This segregation fit a $1: 1: 1: 1$ ratio $\left(\chi^{2}=\right.$ $4.48 ; P=0.21)$. The testcross data confirmed that two independent genes were being inherited.

The $\mathrm{F}_{2}$ population derived from 'Keystone' and 'CM-334' yielded a 47:15:12:21 (R/R:R/S:S/R:S/S) ratio. The individual segregation analyses for root rot resistance and foliar blight resistance in the $\mathrm{F}_{2}$ population indicated that resistance required the presence of two independent genes. When tested for goodness of fit using a chi-square analysis, the expected ratio of 9:7:7:5.4 (R/ $\mathrm{R}: \mathrm{R} / \mathrm{S}: \mathrm{S} / \mathrm{R}: \mathrm{S} / \mathrm{S})$ for the segregation of four independent dominant genes could be rejected $(P=0.0004)$. The observed segregation ratio did, however, fit a 7:2:2:5 ratio $\left(\chi^{2}=4.08 ; P=0.25\right)$ which is consistent with a three dominant gene system in which a single, independent gene is necessary for root rot resistance, and a different single, independent gene is necessary for foliar blight resistance. In addition to these two genes, at least one dominant allele of a third gene must be present for the manifestation of root rot and foliar blight resistance.

The 'Keystone' testcross data for root rot and foliar blight

Table 1. Segregation for resistance ${ }^{\mathrm{z}}$ to Phytophthora capsici root rot in 'Early Jalapeño', 'Keystone Resistant Giant \#3', 'Criollo de Morelos-334', $\mathrm{F}_{1}$, $\mathrm{F}_{2}$ and testcross generations.

\begin{tabular}{|c|c|c|c|c|c|}
\hline \multirow[b]{2}{*}{ Generation $^{y}$} & \multicolumn{2}{|c|}{ Plants (no.) } & \multirow{2}{*}{$\begin{array}{c}\text { Expected } \\
\text { ratio } \\
\text { R:S }\end{array}$} & \multirow[b]{2}{*}{$\chi^{2}$} & \multirow[b]{2}{*}{$P$} \\
\hline & $\mathrm{R}$ & $S$ & & & \\
\hline Parental (Jal) & 0 & 22 & $0: 1$ & 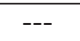 & 1.0 \\
\hline Parental (Key) & 0 & 24 & $0: 1$ & --- & 1.0 \\
\hline Parental (CM) & 24 & 0 & $1: 0$ & --- & 1.0 \\
\hline $\mathrm{F}_{1}(\mathrm{Jal} \times \mathrm{CM})$ & 20 & 0 & $1: 0$ & --- & 1.0 \\
\hline $\mathrm{F}_{1}(\mathrm{CM} \times \mathrm{Jal})$ & 24 & 0 & $1: 0$ & --- & 1.0 \\
\hline $\mathrm{F}_{1}(\mathrm{Key} \times \mathrm{CM})$ & 17 & 0 & $1: 0$ & --- & 1.0 \\
\hline $\mathrm{F}_{1}(\mathrm{CM} \times \mathrm{Key})$ & 23 & 0 & $1: 0$ & --- & 1.0 \\
\hline $\mathrm{F}_{2}(\mathrm{Jal} \times \mathrm{CM})$ & 151 & 65 & $3: 1$ & 3.00 & 0.08 \\
\hline $\mathrm{F}_{2}(\mathrm{Key} \times \mathrm{CM})$ & 131 & 82 & $9: 7$ & 2.39 & 0.12 \\
\hline Testcross $\left(\mathrm{Jal} \times \mathrm{F}_{1}\right)$ & 39 & 28 & $1: 1$ & 1.81 & 0.18 \\
\hline Testcross $\left(\right.$ Key $\left.\times \mathrm{F}_{1}\right)$ & 21 & 74 & $1: 3$ & 0.43 & 0.51 \\
\hline
\end{tabular}

${ }^{\mathrm{z}}$ Rated on a scale of 1 to $9 ; 1=$ no disease symptoms and $9=$ death. Resistant $(\mathrm{R})=$ root disease index score $1-2$, Susceptible $(\mathrm{S})=$ root disease index score 3-9.

yJal = 'Early Jalapeño', Key = 'Keystone Resistant Giant \#3', CM = 'Criollo de Morelos-334'.

Table 2. Segregation for resistance ${ }^{\mathrm{z}}$ to Phytophthora capsici foliar blight in 'Early Jalapeño', 'Keystone Resistant Giant \#3', 'Criollo de Morelos-334', $\mathrm{F}_{1}, \mathrm{~F}_{2}$, and testcross generations.

\begin{tabular}{|c|c|c|c|c|c|}
\hline \multirow[b]{2}{*}{ Generation $^{\mathrm{y}}$} & \multicolumn{2}{|c|}{ Plants (no.) } & \multirow{2}{*}{$\begin{array}{c}\text { Expected } \\
\text { ratio } \\
\text { R:S }\end{array}$} & \multirow[b]{2}{*}{$\chi^{2}$} & \multirow[b]{2}{*}{$P$} \\
\hline & $\mathrm{R}$ & S & & & \\
\hline Parental (Jal) & 0 & 14 & $0: 1$ & --- & 1.0 \\
\hline Parental (Key) & 0 & 15 & $0: 1$ & --- & 1.0 \\
\hline Parental (CM) & 21 & 0 & $1: 0$ & --- & 1.0 \\
\hline $\mathrm{F}_{1}(\mathrm{Jal} \times \mathrm{CM})$ & 19 & 0 & $1: 0$ & --- & 1.0 \\
\hline $\mathrm{F}_{1}(\mathrm{CM} \times \mathrm{Jal})$ & 20 & 0 & $1: 0$ & --- & 1.0 \\
\hline $\mathrm{F}_{1}($ Key $\times \mathrm{CM})$ & 17 & 0 & $1: 0$ & --- & 1.0 \\
\hline $\mathrm{F}_{1}(\mathrm{CM} \times \mathrm{Key})$ & 19 & 0 & $1: 0$ & --- & 1.0 \\
\hline $\mathrm{F}_{2}(\mathrm{Jal} \times \mathrm{CM})$ & 62 & 27 & $3: 1$ & 1.35 & 0.25 \\
\hline $\mathrm{F}_{2}(\mathrm{Key} \times \mathrm{CM})$ & 60 & 36 & $9: 7$ & 1.52 & 0.22 \\
\hline Testcross $\left(\mathrm{Jal} \times \mathrm{F}_{1}\right)$ & 31 & 27 & $1: 1$ & 0.28 & 0.60 \\
\hline Testcross $\left(\right.$ Key $\left.\times \mathrm{F}_{1}\right)$ & 26 & 66 & $1: 3$ & 0.52 & 0.47 \\
\hline
\end{tabular}

${ }^{\mathrm{z}}$ Rated on a scale of 1 to $9 ; 1=$ no disease symptoms and $9=$ death. Resistant $(\mathrm{R})=$ root disease index score $1-2$, Susceptible $(\mathrm{S})=$ root disease index score 3-9.

'⿳Jコ一 = 'Early Jalapeño', Key = 'Keystone Resistant Giant \#3’, CM = 'Criollo de Morelos-334'. 
resulted in a 12:9:14:57 (R/R:R/S:S/R:S/S) ratio. This segregation fit a $1: 1: 1: 5$ ratio $\left(\chi^{2}=1.11 ; P=0.77\right)$. The testcross data substantiates that a three gene system is necessary for root rot and foliar blight resistance in crosses having 'Keystone' as a parent.

\section{Discussion}

In chile (Capsicum annuum), the inheritance of resistance to Phytophthora capsici root rot is determined by different genes than resistance to $P$. capsici foliar blight. When two different pod type parents (bell and jalapeño) were investigated, individuals in both $\mathrm{F}_{2}$ populations segregated for root rot resistance and foliar blight resistance in accordance with predictable genetic ratios. If the resistant phenotype was conditioned by the same gene(s), no segregation could have been possible and the $\mathrm{F}_{2}$ plants would have either been root rot and foliar blight resistant or root rot and foliar blight susceptible.

Previous results from inheritance studies into phytophthora resistance in 'CM-334' have resulted in contradictory results. GuerreroMoreno and Laborde (1980) proposed a recessive two-gene inheritance pattern with no linkage. Gil Ortega et al. (1991) found that the model that best fit their results involved inheritance of three resistance genes $\left(R_{1}, R_{2}, R_{3}\right)$ from 'CM-334'. Their resistance is expressed when a plant possesses the three genes in a heterozygous state $\left(R_{1}\right.$ $\mathrm{R}_{2} \mathrm{R}_{3}$ ), or possesses at least four alleles of the three genes in any arrangement (i.e., $R_{1} R_{1} r_{2} r_{2} R_{3} R_{3}, r_{1} r_{1} R_{2} R_{2} R_{3} R_{3}, R_{1} R_{1} R_{2} R_{2} r_{3} r_{3}$ ). Reifschneider et al. (1992) observed a 13:3 (resistant/susceptible) ratio in the $\mathrm{F}_{2}$ generation. This pattern was consistent with the two gene model with dominant and recessive epistasis described by Fehr (1991). According to this model, plants with either a genotype of $\mathrm{R}_{1}$ or $r_{2} r_{2}$ will express resistance.

The previously reported inheritance patterns do not agree with the two- and three-gene models proposed for 'CM-334' when crossed with 'Early Jalapeno' and 'Keystone'. The discrepancy may be the result of different experimental conditions and the $P$. capsici isolate used, as postulated by Guerrero-Moreno and Laborde (1980) to explain differences in previous inheritance studies. An additional important factor, however, was the use of different susceptible parents. While past research has focused on the sources of resistance genes, this study establishes that differences in the susceptible parent's genetic background can change the results of an inheritance study.

The 9:3:3:1 segregation observed in the $F_{2}$ population derived from the cross of 'CM-334' and 'Early Jalapeno' indicated one dominant gene for root resistance and a separate dominant gene for foliar resistance. The distinctive 7:2:2:5 segregation ratio observed in the 'Keystone'-derived $\mathrm{F}_{2}$ population, can be explained by the inheritance of a single, independent gene for root rot resistance, and a separate single, independent gene for foliar blight resistance. In addition to these two genes, at least one dominant allele of a third gene is shared by both systems, and must be present for manifestation of root rot and foliar blight resistance. The implication of such a genetic segregation is that one gene that provides an overall protection to $P$. capsici is required for plants from the 'Keystone' genetic background. This gene does not provide full protection by itself, however, and requires the presence of an additional gene for manifestation of root or foliar resistance. The genetic background of 'Early Jalapeno' may already include that gene, so that only one gene from 'CM-334' is needed to manifest root or foliar resistance.

The use of strictly controlled experimental parameters allowed for the observation of differences in inheritance for phytophthora root rot and foliar blight resistance in this study. Efforts in breeding chile cultivars resistant to $P$. capsici may be ineffective if inoculation methods are not designed to distinguish resistance versus susceptibility for root rot and foliar blight disease syndromes. Genes for both resistance mechanisms must be incorporated to successfully breed chile accessions possessing phytophthora root rot and foliar blight resistance.

\section{Literature Cited}

Alcantara, T.P. and P.W. Bosland. 1994. An inexpensive disease screening technique for foliar blight of chile pepper seedlings. HortScience 29:1182-1183.

Barksdale, T.H., G.C. Papavizas, and S.A. Johnston. 1984. Resistance to foliar blight and crown rot of pepper caused by Phytophthora capsici. Plant Dis. 68:506-509.

Bartual, R., A. Lacasa, J.I. Marsal, and J.C. Tello. 1994. Epistasis in the resistance of pepper to phytophthora stem blight (Phytophthora capsici L.) and its significance in the prediction of double cross performances. Euphytica 72:149-152.

Bonde, R., F.J. Stevenson, and C.F. Clark. 1940. Resistance of certain potato varieties and seedling progenies to late blight in the tubers. Phytopathology 30:733-748.

Bosland, P.W. and D.L. Lindsey. 1991. A seedling screen for phytophthora root rot of pepper, Capsicum annuum. Plant Dis. 75:1048-1050.

Bowers, J.H. and D.J. Mitchell. 1991. Relationships between inoculum level of Phytophthora capsici and mortality of pepper. Phytopathology 81:178-184.

Budin, K.Z., V.L. Broksh, and M.M. Khromtsova. 1978. Resistance to Phytophthora infection in hybrids obtained from crosses of the dihaploid S. tuberosum L. with wild and cultivated forms of Solanum, p. 168-177. In: A.Ya. Kameraz (ed.). Systematics, breeding and seed production of potatoes. Amerind Publishing Co. Pvt. Ltd., New Delhi, India.

Fehr, W.R. 1991. Principles of cultivar development. Theory and technique. vol 1. Macmillian, New York.

Gil Ortega, R., C.P. Espanol, and J.C. Zueco. 1991. Genetics of resistance to Phytophthora capsici in the pepper line 'SCM-334'. Plant Breeding 107:50-55.

Goldberg, N.P. 1995. Chile pepper diseases. N.M. State Univ. Coop. Ext. Circ. 549.

Guerrero-Moreno, A. and J.A. Laborde. 1980. Current status of pepper breeding for resistance to Phytophthora capsici in Mexico. Synopses of the IVth Meeting of the Capsicum Working Group of Eucarpia. I.V.T., Wageningen, The Netherlands. p 52-56.

Hartmann, H.T., D.E. Kester, and F.T. Davies, Jr. 1990. Plant propagation-Principles and practices. 5th ed. Prentice Hall, Englewood Cliffs, N.J.

Howard, H.W. 1978. The production of new varieties, p. 607-646. In: P.M. Harris. (ed.). The potato crop. Chapman \& Hall, London, England. Leonian, L.H. 1922. Stem and fruit blight of peppers caused by Phytophthora capsici. Phytopathology 12:401-408.

Lindsey, D.L., J.R. Sollars, C.M. Liddell, and C.L. Biles. 1996. 1992 Producer survey of foliar chile pepper diseases in New Mexico. N.M. State Univ. Agr. Expt. Sta. Res. Rpt. 708.

Reifschneider, F.J.B., L.S. Boiteux, P.T. Della Vecchia, J.M. Poulos, and N. Kuroda. 1992. Inheritance of adult-plant resistance to Phytophthora capsici in pepper. Euphytica 62:45-49.

Reifschneider, F.J.B., A.C. Café-Filho, and A.M. Rego. 1986. Factors affecting expression of resistance in pepper (Capsicum annuum) to blight caused by Phytophthora capsici in screening trials. Plant Pathol. 35:451-456.

Ristaino, J.B. 1991. Influence of rainfall, drip irrigation, and inoculum density on the development of phytophthora root and crown rot epidemics and yield in bell pepper. Phytopathology 81:922-929.

Rudorf, W., P. Schaper, H. Ross, M. Baerecke, and M. Torka. 1950. The breeding of resistant varieties of potatoes. Amer. Potato J. 27:222-235. Tuite, J. 1969. Plant pathological methods-Fungi and bacteria. Burgess Publishing Co., Minneapolis, Minn.

Weber, G.F. 1932. Blight of peppers in Florida caused by Phytophthora capsici. Phytopathology 22:775-780. 